\title{
Blastocystis hominis ile İlişkili Henoch-Schönlein Purpura Vakası
}

\author{
The Case of Henoch-Schönlein Purpura Associated with Blastocystis hominis
}

\author{
Murat Tutanç ${ }^{1}$, İbrahim Şilfeler', Tümay Özgür², Vicdan Köksaldı Motor ${ }^{3}$, Ahmet ibrahim Kurtoğlu \\ 'Mustafa Kemal Üniversitesi Tayfur Ata Tıp Fakültesi, Çocuk Sağlığı ve Hastalıkları Anabilim Dalı, Hatay, Türkiye \\ ${ }^{2}$ Mustafa Kemal Üniversitesi Tayfur Ata Tıp Fakültesi, Patoloji Anabilim Dalı, Hatay, Türkiye \\ ${ }^{3}$ Mustafa Kemal Üniversitesi Tayfur Ata Tıp Fakültesi, Enfeksiyon ve Klinik Mikrobiyoloji Anabilim Dalı, Hatay, Türkiye
}

\section{ÖZET}

Blastocystis hominis (B. hominis), sıklıkla immun yetmezliği olan hastalarda gastrointestinal semptomlara sebep olan sağlıklı insanlarda patojenitesi tartışmalı bir parazittir. Sağlıklı insanlarda gastrointesital sistem dışı semptomları nadiren de olsa rapor edilmiştir. HenochSchönlein Purpura (HSP) vasküliti IgA depolanması ile ilgili karakterize akut küçük damarları tutan çeşitli enfeksiyon etkenlerinin etyolojide suçlandığı otoimmün bir hastalıktır. HSP tanısıyla takip edilen 30 aylık erkek çocukta steroid tedavisine rağmen iki gün içinde tekrarlayan semptomlar sonucunda yapılan tetkiklerinde gaitada B. hominis saptandı. kotrimaksazol ve steroid tedavisinden sonra döküntü, karın ağrısı ve artrit bulguları düzeldi. Bu yazıda literatürde ilk olduğunu düşündüğümüz B. hominis'le ilişkili HSP vakasını sunduk.

(Turkiye Parazitol Derg 2013; 37: 135-8)

Anahtar Sözcükler: Çocuk, blastocystis hominis, Henoch-Schönlein Purpura

Geliş Tarihi: 10.12 .2012

Kabul Tarihi: 16.01.2013

\section{ABSTRACT}

Blastocystis hominis (B. hominis) is a parasite that often causes gastrointestinal symptoms in patients with immune deficiency and has a controversial pathogenicity in healthy people, although some symptoms are reported outside of the gastrointestinal system in healthy persons. Henoch-Schönlein Purpura (HSP) vasculitis is an acute autoimmune disease characterised by lgA storage of small vessels that is believed to include infectious factors in its aetiology. A 30-month follow-up with a boy diagnosed with HSP being treated with steroid therapy showed that he had recurrent symptoms within two days, and B. hominis was detected in the faecal analysis. His symptoms including rash, abdominal pain, and arthritis improved after treatment with steroid and co-trimaksazol. This paper is the first to present a case of HSP associated with B. hominis. (Turkiye Parazitol Derg 2013; 37: 135-8)

Key Words: Child, blastocystis hominis, Henoch-Schönlein Purpura

Received: 10.12.2012

Accepted: 16.01.2013

\section{GiRiş}

Özellikle tropikal ve subtropikal ülkelerde daha sık olarak rastlanılan Blastocystis Hominis (B. hominis), sınıflandırması, yaşam döngüsü, biyolojik özellikleri, epidemiyolojisi, özellikle de patojenitesi açısından hakkında çelişkili görüşler içeren bir protozoondur (1). B. hominis kültür ve direkt dışkı incelemelerinde farklı morfolojik tipleri görülebilmek- tedir. Nitelik ve patojenite ile B. hominis'in morfolojik formlarının ilişkisi henüz bilinmemektedir. Gaita numunelerinde en sık sırasıyla vakuoler, granüler, multivakuoler ve kist formunun görüldüğü tespit edilmiştir (Şekil 1). Ameboid form çok nadir olduğu, bunun yanında insan bağırsağında avakuoler formun bulunduğu düşünülmektedir $(2,3)$.

Yazışma Adresi / Address for Correspondence: Dr. Murat Tutanç, Mustafa Kemal Üniversitesi Tayfur Ata Tıp Fakültesi, Çocuk Sağlığı ve Hastalıkları Anabilim Dalı, Hatay, Türkiye Tel: +90326 2291000 E-posta: drtutanc@hotmail.com doi:10.5152/tpd.2013.29 


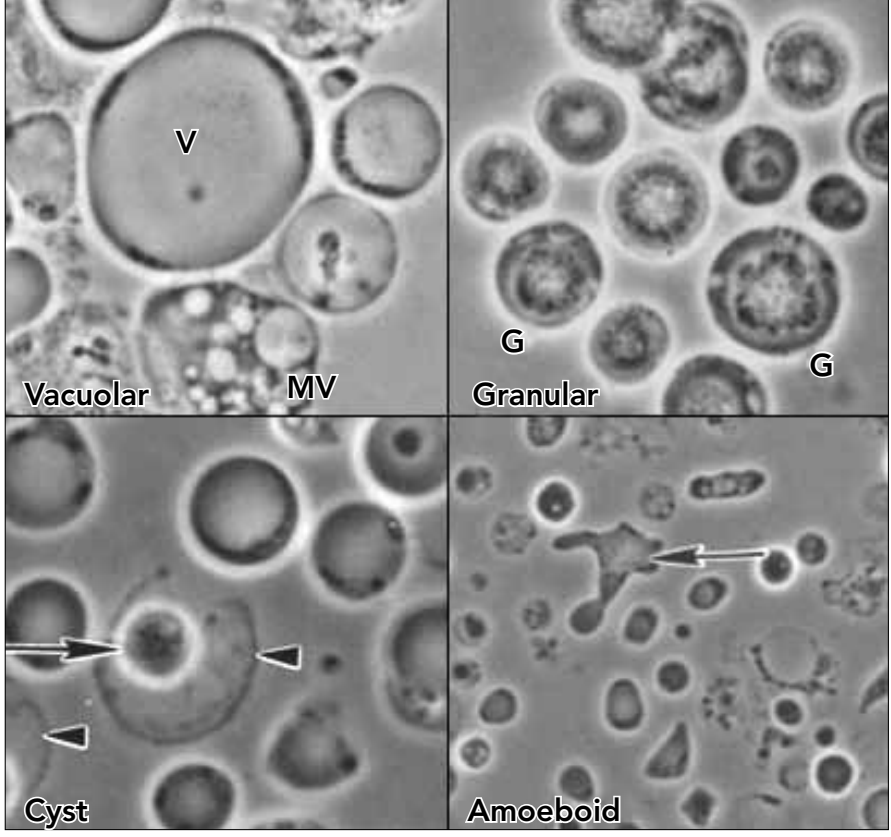

Şekil 1. B. Hominisin formları

Fekal oral yolla bulaşan $B$. hominis gastrointestinal belirtileri olan bireylerde, turist ishallerinde, irritabl bağırsak sendromu olan hastalarda, immün yetmezlikli hastalarda kontrol gruplarına göre daha sık olduğu söylenmektedir (1). B. hominis'e karşı spesifik IgM tipinde monoklonal antikor yanıtı olduğu bildirilmiştir (4). B. hominis'in sitopatik etki yaratmamasına karşın, hücrelerden IL-8 ve granülosit makrofaj koloni sitümüle edici faktörün salınmasını indüklediği gösterilmiştir (5). Bir kemokin olan IL-8 başta nötrofiller olmak üzere monosit ve T lenfositleri aktive ettiği, GM-CSF ise nötrofil ve eozinofiller için güçlü bir kemoatraktan özellik taşıdığı bilinmektedir (1). Barsak dışı bulgular olarak hepetosplenomegali, deri döküntüleri ve artrit ile birliktelik rapor edilmiştir $(6,7)$. Ülkemizde B. hominis'e karşı antiprotozoal ilaçların etkisinin araştırıldığı çalışmada en etkili ilaçlar sırasıyla ornidazol, metronidazol, azitromisin, itrakonazol, kotrimaksazol olarak saptanmıştır (8). Tedavi konusu tartışmalı olmakla beraber hastanın belirtilerini açıklayacak başka bir neden bulunamadığında $B$. hominis'in eradike edilmesi gerektiği söylenmektedir (9).

Henoch-Schönlein Purpurası (HSP) kendi kendini sınırlayan, sistemik, nongranulomatöz, otoimmün, karmaşık çoklu organ tutulumu olan, küçük damarları tutan bir vaskülittir (10). Etydolojisi tam olarak bilinmemekte ancak enfeksiyonlar ile ilişki (bakteriyel, viral, paraziter) ve ilaçlar, aşılama, tümörler ile birliktelikler bildirilmiştir (11). Özellikle 430 vakalık bir seride 158 hastanın etyoojisinin enfeksiyonlarla ilgili olabileceği bildirilmektedir (12). Çocuklarda en sık görülen vaskülit tipi olan HSP cilt, eklem, gastrointestinal sistem ve böbrek tutulumu ile karakterizedir (13). Nadir olarak da merkezi sinir sistemi, akciğer ve testis tutulumu olabileceği de söylenmektedir (12).

Hastalık Çocuklarda \%94 ve yetişkinlerde \%89 oranda kendini sınırlar. HSP için semptomatik döküntü ve artrit gibi belirtiler için asetaminofen ve nonsteroid antiinflamatuvar ilaçlar tedavide yeterli olmaktadır (14). Sistemik steroidler, şiddetli kaşıntı olan ödem, şiddetli kolik tarzında karın ağrısı, bulantı, kusma, böbrek, skrotum ve testis tutulumu olan hastalarda endikedir. Genellikle

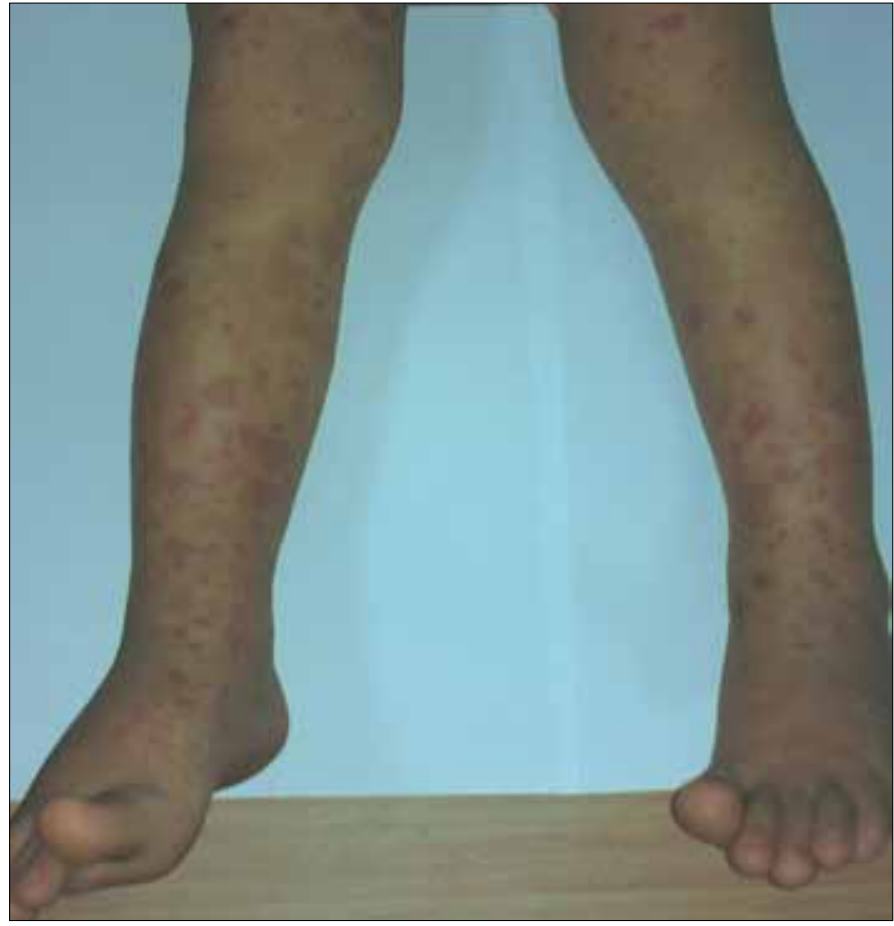

Şekil 2. Hastanın alt ekstremitelerinde palpabl purpurik döküntüler

prednizon veya metilprednizolon bir-iki hafta boyunca, gün başına $2 \mathrm{mg} / \mathrm{kg}$ dozunda kullanılır (15).

\section{OLGU SUNUMU}

Otuz aylık erkek hastanın iki gün önce ayak bileklerinde kızarıklık başlamış. Hasta gittiği merkezde alerji tanısıyla iki gün üst üste steroid ve antihistaminik yapılarak eve gönderilmiş. Döküntüleri tekrarlayan, şikayetlerine karında ve ayak bileğinde ağrı, ayak bileğinde şişlik ve hareket kısıtlılı̆ı da eklenen, bu bulguşarıyla sevk edilen hasta yatırıldı. Fizik muayenesinde genel durumu iyi, büyüme geriliği (boy ve kilosu 3-10 persentil arasında), ciltte üst ekstremitelerde, ayak ve ayak bileklerinde (Şekil 2), uyluk posteriorunda gluteaya doğru en büyüğü bir cm olan palpabl purpurik döküntüleri vardı. Diğer sistem ve vital bulgu muayenelerinde patoloji yoktu. Yapılan laboratuar incelemesinde hafif anemi ve IgA yüksekliği [Hb: $12 \mathrm{mg} / \mathrm{dL}$, trombosit:259.000/ $\mu \mathrm{L}$, INR: 1,31, gaitada gizli kan menfi, idrarda eritrosit menfi, kan sedimantasyonu $11 \mathrm{~cm} / \mathrm{h}, \operatorname{lgA}: 168$, serolojik (salmonella, brusellayı romatoid faktör ve CRP) ve immunolojik (ANA, anti-ds DNA, anti-Sm, ACL, IgM ve IgG veANCA) testler menfi] dışında patolojik bulgu yoktu. Döküntülerden alınan cilt biyopsi sonucu geç dönem lökositoklastik vaskülit ile uyumlu idi (Şekil 3). Hastaya cilt ve eklem tutulumu için ibuprofen şurup ve sukralfat şurup başlandı. Şikayetleri azalan hastanın tedavinin üçüncü gününde döküntüleri ve karın ağrısı arttı. Bu durumda HSP'ile birliktelik gösterme ihtimaline karşı enfeksiyonenfestasyon etkenleri kültür, direk bakı ve serolojik olarak tarandı. İshali de olan hastada yapılan gaita direk incelemesinde B. hominis (vakuollü form) saptandı. Gaitada başka parazite rastlanmadığı gibi farklı enfeksiyon-enfestasyon etkenlerine de rastlanmadı. Hastanın tedavisine kotrimaksazol ve sistemik steroid başlandı. Tedaviye bir hafta devam edildi. Şikayetleri azalan hastanın döküntü ağrı şişlik şikayetleri tekrar etmedi. 


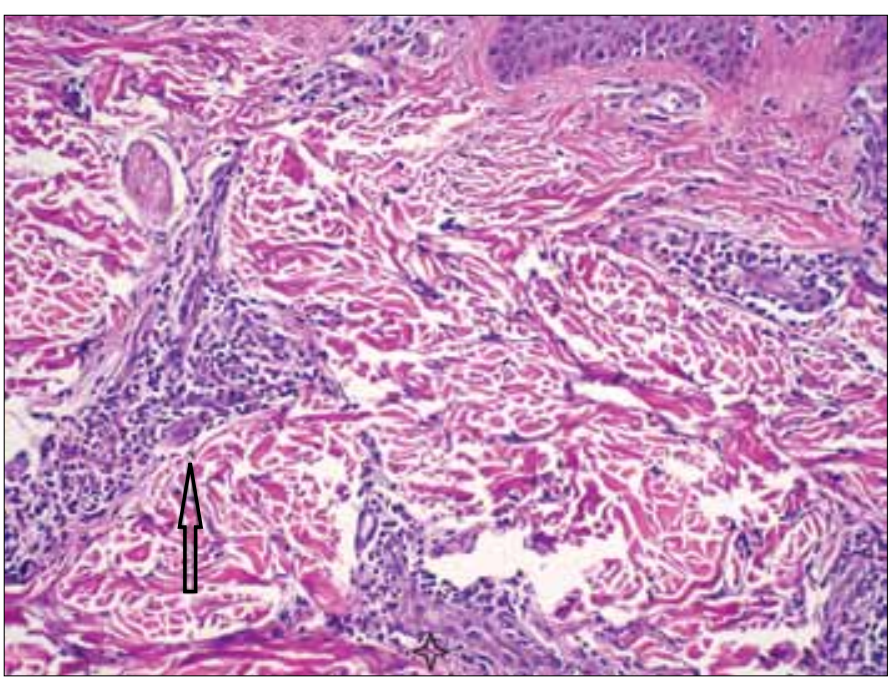

Şekil 3. Mixt inflammatuar hücreler: eizinofiller, polimorf çekirdekli lökositler ve nükleer kırıntılar (ok) Vasküler kanalların luminal yüzeyindeki fibrin eksudalar. (yıldız) (HEX200)

Hastanın bir aylık takibinde kontrol gaita incelemesi ve diğer klinik belirtilerin tekrarlaması ve başka bir komplikasyon olmadı.

\section{TARTIŞMA}

Bizim bilgilerimize göre, sunulan hasta $B$. hominis'le ilişkili ilk HSP vasküliti vakasıdır. Sağlıklı insanlarda patojenitesi tartışmalı olan $B$. hominis'in sebep olduğu belirti ve bulgular, literatürde yorgunluk, iştahsızlık, gaz ve diğer nonspesifik gastrointestinal belirti ve rahatsızlık hissi, karın ağrısı, krampalar, bulantı ya da ishal, fekal lökosit, rektal kanama, eozinofili, hepatomegali, splenomegali, kutanöz döküntü ve kaşıntı, nadiren ateş, eklem ağrıları, şişme ve sinovyal sıvı olarak belirtilmektedir (2). Bir kemokin olan IL-8 başta nötrofiller olmak üzere monosit ve $T$ lenfositleri aktive ettiği, GM-CSF ise nötrofil ve eozinofiller için güçlü bir kemoatraktan özellik taşıdığı bilinmektedir (1). Bu kemokinlerin hastalarda irritabl barsak sendromu ile ilişkili olabileceği söylenmektedir (16). Barsak dışı bulgular olarak hepetosplenomegali, deri döküntüleri ve artrit ile birliktelik rapor edilmiştir $(6,7)$. Bu bulgular $B$. hominis'in sistemik sorunlara da yol açabileceğini göstermektedir. Hastamız multiorgan tutulumu olabilen lökositoklastik vaskülit ile birliktelik gösteren $B$. hominis vakasıydı.

HSP vasküliti IgA depolanması ile ilgili karakterize akut küçük damarları tutan otoimmün bir hastalıktır (12). Çeşitli enfeksiyon etkenlerinin sitokinler aracılığı ile endoteli aktive etmesiyle potansiyel olarak HSP'yi tetikledikleri düşünülmektedir (17). Literatürde influenze virus ( $\mathrm{H} 1 \mathrm{~N} 1)$, ebstein bar virus mikoplazma, adenovirus, parvovirus ve sinüzit enfeksiyonları, aşılar sonrasında HSP vakaların bulunmaktadır (18-23). Literatürde ayrıca enfeksiyöz etkenlerin etyolojide \%36.8 oranında suçlandığı vaka serisi bulunmaktadır (12). Bu bilgiler ışığında enfeksiyonlarla HSP ilişkisi literatürde çokça tartışıldığı söylenebilir. Mevcut bilgilerimize göre HSP ile ilişkilendirilmiş bir paraziter hastalık bulunmamaktadır. Sunulan vaka, B. hominis ilişkilendirilen ilk vaka olmasının yanında geniş paraziter hastalık grubu için de ilk olma özelliği taşımaktadır.

\section{SONUÇ}

Etyolojisi tam olarak açığa kavuşmamış olan HSP'da olası etkenler arasında enfeksiyonları takip ederek inflamasyona sebep olan immunolojik olayların olduğu ileri sürülmektedir (11-14). HSP'ye yönelik enfeksiyon etkeni geriye dönük öykü ve yapılan serolojik testlere dayandırılmaktadır $(12,18)$. Bu vaka ile HSP tanısı konduğunda sorumlu etken olarak $B$. hominis ve diğer parazitlerin varlığının araştırılmasının faydalı olacağı kanaatindeyiz.

\section{Çıkar Çatışması}

Yazarlar herhangi bir çıkar çatışması bildirmemişlerdir.

Hakem değerlendirmesi: Dış bağımsız.

\section{Yazar Katkıları}

Fikir - M.T.; Tasarım - M.T.; Denetleme - V.K.M.; Kaynaklar - I.Ş.; Malzemeler - A.I.K.; Veri toplanması ve/veya işlemesi - V.K.M., T.Ö.; Analiz ve/veya yorum - M.T.; Literatür taraması - A.I.K.; Yazıyı yazan - M.T.; Eleştirel İnceleme - T.Ö.; Diğer - M.T., I.Ş.

\section{Conflict of Interest}

No conflict of interest was declared by the authors.

Peer-review: Externally peer-reviewed.

\section{Author Contributions}

Concept - M.T.; Design - M.T.; Supervision - V.K.M.; Funding i.Ş.; Materials - A.I.K.; Data Collection and/or Processing - V.K.M., T.Ö.; Analysis and/or Interpretation - M.T.; Literature Review A.I.K.; ; Writing - M.T.; Critical Review - T.Ö.; Other - M.T., I.Ş.

\section{KAYNAKLAR}

1. Al FD, Hökelek M. Is Blastocystis hominis an opportunist agent? Turkiye Parazitol Derg 2007; 31: 28-36.

2. Stenzel DJ, Boreham PF. Blastocystis hominis revisited. Clin Microbiol Rev 1996; 9: 563-84.

3. Tan KS, Singh M, Yap EH. Recent advances in Blastocystis hominis research: hot spots in terra incognita. Int J Parasitol 2002; 32: 789804. [CrossRef]

4. Tan SW, Ho LC, Moe KT, Chen XQ, Ng GC, Yap EH, et al. Production and characterization of murine monoclonal antibodies to Blastocystis hominis. Int J Parasitol 1996; 26: 375-81.[CrossRef]

5. Long HY, Handschack A, König W, Ambrosch A. Blastocystis hominis modulates immune responses and cytokine release in colonic epithelial cells. Parasitol Res 2001; 87: 1029-30.

6. Garavelli PL, Scaglione L. Blastocystis hominis infection in AIDS and correlated pathologies. Minerva Med 1990; 81: 91-2.

7. Lee MG, Rawlins SC, Didier M, DeCeulaer K. Infective arthritis due to Blastocystis hominis. Ann Rheum Dis 1990; 49: 192-3. [CrossRef]

8. Hamamcı B, Yazar S, Şahin I. Blastocystis hominis'in in vitro kültürü ve antiprotozoal ilaçların in vitro etkilerinin araştııılması. Erciyes Üniv Sağlık Bilimleri Dergisi 2004; 13: 7-15.

9. Doyle PW, Helgason MM, Mathias RG, Proctor EM. Epidemiology and pathogenicity of Blastocystis hominis. J Clin Microbiol 1990; 28 116-21.

10. Sohagia AB, Gunturu SG, Tong TR, Hertan HI. Henoch-schonlein purpura-a case report and review of the literature. Gastroenterol Res Pract 2010: 597648.

11. Chen KR, Carlson JA. Clinical approach to cutaneous vasculitis. Am J Clin Dermatol 2008; 9: 71-92. [CrossRef]

12. Anil M, Aksu N, Kara OD, Bal A, Anil AB, Yavaşcan O, et al. HenochSchonlein purpura in children from western Turkey: a retrospective analysis of 430 cases. Turk J Pediatr 2009; 51: 429-36.

13. Saulsbury FT. Clinical update: Henoch-Schonlein purpura. Lancet 2007; 369: 976-8. [CrossRef] 
14. Roberts PF, Waller TA, Brinker TM, Riffe IZ, Sayre JW, Bratton RL. HenochSchonlein purpura: a review article. South Med J 2007; 100: 821-4. [CrossRef]

15. Ronkainen J, Koskimies O, Ala-Houhala M, Antikainen M, Merenmies $J$, Rajantie J, et al. Early prednisone therapy in Henoch-Schonlein purpura: a randomized, double-blind, placebo-controlled trial. J Pediatr 2006; 149: 241-7. [CrossRef]

16. Giacometti A, Cirioni O, Fiorentini A, Fortuna M, Scalise G. Irritable bowel syndrome in patients with Blastocystis hominis infection. Eur J Clin Microbiol Infect Dis 1999; 18: 436-9. [CrossRef]

17. Brogan PA. What's new in the aetiopathogenesis of vasculitis? Pediatr Nephrol 2007; 22: 1083-94. [CrossRef]

18. Urso R, Bevilacqua N, Gentile M, Biagioli D, Lauria FN. Pandemic 2009 H1N1 virus infection associated with purpuric skin lesions: a case report. J Med Case Rep. 2011; 5: 132. [CrossRef]
19. Guissa VR, Aragão PA, Marques HH, Jacob CM, Silva CA. Chronic active Epstein-Barr virus infection mimicking Henoch-Schonlein purpura. Acta Reumatol Port 2010; 35: 513-7.

20. Tizard EJ. Henoch-Schonlein purpura. Arch Dis Child 1999; 80: 380-3. [CrossRef]

21. Nakaseko H, Uemura O, Nagai T, Yamakawa S, Hibi Y, Yamasaki Y, et al. High prevalence of sinusitis in children with henoch-schonlein purpura. Int J Pediatr 2011; 2011: 562638.

22. Goodman MJ, Nordin JD, Belongia EA, Mullooly JP, Baggs J. Henoch-Scholein purpura and polysaccharide meningococcal vaccine. Pediatrics 2010; 126: e325-9. [CrossRef]

23. Chave T, Neal C, Camp R. Henoch-Schonlein purpura following hepatitis B vaccination. J Dermatolog Treat 2003; 14: 17981. [CrossRef] 